\title{
Identification of the Sex Pheromone of the Webbing Coneworm Moth, Dioryctria disclusa (Lepidoptera: Pyralidae) ${ }^{1}$
}

\author{
WENDY L. MEYER, GARY L. DEBARR, ${ }^{2}$ C. WAYNE BERISFORD, ${ }^{3}$ LARRY R. BARBER, ${ }^{4}$ AND \\ WENDELL L. ROELOFS \\ Department of Entomology, New York State Agricultural Experiment Station, Geneva, New York 14456 \\ ABSTRACT \\ Environ. Entomol. 11: 986-988 (1982) \\ A sex pheromone component for the webbing coneworm, Dioryctria disclusa, has been identified as \\ (Z)-9-tetradecenyl acetate. Traps baited with nubber septa impregnated with this compound at loadings \\ of 30 to $300 \mu \mathrm{g}$ caught the same as or significantly better than traps baited with two virgin female \\ moths. Addition of 3 to $30 \%$ of the $E$ isomer did not increase trap catch, and only (Z)-9-tetradecenyl \\ acetate was found in the female extract.
}

The webbing coneworm, Dioryctria disclusa Heinrich is found in the southern United States on loblolly pine, Pinus taeda L., and Virginia pine, P. viginiana, Mill., where it attacks and destroys second-year cones (Neunzig et al. 1964, Ebel et al. 1975). It usually causes minor economic losses (Yates and Ebel 1978), but outbreaks in loblolly pine seed orchards in 1979 and 1980 had severe economic impact on production of genetically improved seed (Barber and DeBarr, unpublished data). The presence of a female-produced sex pheromone was demonstrated (DeBarr and Berisford 1981), and a reliable monitoring system was needed for this species, so we initiated a cooperative project to isolate and identify the chemical component(s). This is the first report identifying a sex pheromone for a species in the genus Dioryctria.

\section{Materials and Methods}

Cones infested with $D$. disclusa larvae were collected from loblolly pine orchards in Georgia or North Carolina from 24 April to 16 May 1980. The cones were dissected, and 3rd to 5th instar larvae were removed and reared individually at $28^{\circ} \mathrm{C}$ in $12-\mathrm{ml}$ plastic cups containing artificial diet (Fedde 1974). Upon pupation, the sexes were separated, and the insects were allowed to emerge on a photocycle of LD $16: 8$ at $25^{\circ} \mathrm{C}$ and were collected daily.

The pheromone gland of this species appeared to be a ring of modified intersegmental membrane between abdominal segments 8 and 9, similar to the gland described for D. abietella (Fatzinger 1972). Crude female extract was prepared by taking 3- to 4-day-old females during their calling period, $4 \mathrm{~h}$ into their scotophase (DeBarr and Berisford 1981), and excising the ovipositor just anterior to the 9 th abdominal segment. Removing just this portion of the ovipositor minimized the amount of oils extracted. The abdominal tips were transferred to a 4-ml vial containing dichloromethane and extracted overnight. After $24 \mathrm{~h}$, the extract was pipetted into another vial and stored at $-10^{\circ} \mathrm{C}$ until use.

'Received for publication 9 December 1981 0602

2USDA Forest Service, Southeastern Forest Experiment Station, Athens, GA

${ }^{3}$ Dept. of Entomology, University of Georgia, Athens, GA 30602

"USDA Forest Service, Southeastem Area, State and Private Forestry, Asheville, NC 28803.
Electroantennograms (EAG) were conducted as described by Roelofs (1977). Responses were recorded from a digital voltmeter display (Bjostad and Roelofs 1980).

The following gas-liquid chromatography (GLC) phases were used in glass columns, OV-101 (methyl silicone, $3 \%$ on 100 - to 120 -mesh Gas-Chrom $\mathrm{Q}, 4 \mathrm{~mm}$ by 1.8 $\mathrm{m}$ ) and XF-1150 (GE XF-1150, 50\% cyanoethyl, methyl silicone, $10 \%$ on 100 - to 120 -mesh Chromosorb W AWDMCS, $2 \mathrm{~mm}$ by $1.8 \mathrm{~m}$ ). Mass spectra were obtained with a HP-5985 GC-MS interfaced with a 10-m OV101 glass capillary column.

Chemicals used for field testing were obtained from the following sources: (Z)-9-tetradecenyl acetate (Z914:Ac) and (Z)-9-dodecenyl acetate (Z9-12:Ac) were from Farchan Company (Willoughby, Ohio); E9-14:Ac was synthesized in our laboratory; dodecyl acetate (12:Ac) was from Eastman Co. (Rochester, N.Y.). The unsaturated acetates contained ca. $1 \%$ of the opposite geometrical isomer as indicated by GLC analysis on XF1150.

Field tests were conducted from 24 May to 30 June 1980, in Putnam County, Ga. (test 1), Beaufort County, N.C. (test 2), Halifax County, N.C. (test 3), and New Kent County, Va. (test 4). The pine seed orchards used were loblolly pine 12 to $18 \mathrm{~m}$ high, in rows spaced 4.5 or 6 by $9 \mathrm{~m}$. Blocks of trees equal to the number of treatments were selected, and treatments were randomly assigned to trees within each block. Pherocon 1C traps (Zoecon Co., Palo Alto, Calif.) were used and baited with a rubber septum dispenser (A. H. Thomas Co., Philadelphia, $\mathrm{Pa}$.) or two live virgin female $D$. disclusa held in a divided cylindrical screen wire cage, $5 \mathrm{~cm}$ in length and $2.5 \mathrm{~cm}$ in diameter. The traps were hung in the upper $3 \mathrm{~m}$ of the tree (DeBarr and Berisford 1981). Trap catches were counted at 1- to 3-day intervals, and male moths were removed. Females were replaced when dead or at 5- to 7-day intervals. Every 3 to 5 days the traps were rerandomized. Test 1 was replicated four times, whereas tests 2,3 , and 4 were replicated five times each.

\section{Results}

Crude female extract was collected from OV-101 $\left(190^{\circ} \mathrm{C}\right)$ in 1 -min fractions and assayed for EAG activity. The only activity occurred between 5 and $7 \mathrm{~min}$, 
with tetradecyl acetate (14:Ac) having a retention time of $6.4 \mathrm{~min}$. These active fractions were combined and collected from XF-1150 $\left(170^{\circ} \mathrm{C}\right)$ in $1-\mathrm{min}$ fractions. EAG activity occurred between 5 and $8 \mathrm{~min}$, with 14:Ac and Z9-14:Ac having retention times of 5.0 and $5.9 \mathrm{~min}$, respectively. When the collected material was injected on OV-101, a peak was produced at a retention time of $16.6 \mathrm{~min}$ with an impurity at $15.3 \mathrm{~min}$. Z9-14:Ac under the same conditions had a retention time of $16.6 \mathrm{~min}$, whereas 14:Ac had a retention time of $17.7 \mathrm{~min}$. On XF-1150, the retention times of Z9-14:Ac and E9-14:Ac were 6.8 and $6.3 \mathrm{~min}$, respectively. Injection of the active material produced a peak with a retention time of $6.7 \mathrm{~min}$ as well as other later impurity peaks. No peak with a retention time corresponding to E9-14:Ac was observed, but an amount smaller than $10 \%$ of Z9-14:AC would not have been detected, due to the small amount of collected active material.

A mass spectrum (EI, 70eV) of OV-101-collected material exhibited an M-60 ion at $194 \mathrm{~m} / \mathrm{e}$, which is characteristic of a monounsaturated 14-carbon acetate. The spectrum was identical to authentic Z9-14:Ac. Further chemical tests were not possible, due to the small amounts of material present. We estimate that each female contained ca. $0.5 \mathrm{ng}$ of Z9-14:Ac.

EAGs to $10 \mu \mathrm{g}$ of synthetic 12-carbon, 14-carbon, and 16-carbon monounsaturated acetates, alcohols, and aldehydes on filter paper showed the highest millivolt


that of a standard (E5-14:Ac, $1.30 \pm 0.36$ SEM). These data support (Roelofs 1977) the GLC and mass spectral analyses in an assignment of Z9-14:Ac for the main pheromone component.

Field test results (Table 1) show that $30 \mu \mathrm{g}$ of $\mathrm{Z9}$ 14:Ac alone captured male $D$. disclusa in traps as well as or better than virgin females. Catches with dosages of 100,300 , and $3,000 \mu \mathrm{g}$ (tests 1 and 2) were not significantly different from the $30-\mu \mathrm{g}$ dosage, but when the dosage was lower than $30 \mu \mathrm{g}$ (test 2), trap catch was significantly decreased. To test the possibility that small amounts of the opposite geometrical isomer would enhance trap catch we added 3,10, and 30\% E9-14:Ac and found there was no significant increase in trap catch (test 3). Indeed, when 30\% E9-14:Ac was added a significant decrease in male capture occurred.

At this time we were also conducting field tests, involving Z9-12:Ac and 12:Ac, for another Dioryctria sp., $D$. clarioralis (Walker). When included in a test for $D$. disclusa (test 4), no increase in trap catch was observed when either Z9-12:Ac (1:20) or 12:Ac (1:1) was added to Z9-14:Ac.

\section{Discussion}

The chemical and biological data show that Z9-14:Ac is the main sex pheromone component produced and perceived by $D$. disclusa. 29-14:Ac is also a pheromone component of another pyralid species, Ephestia cautella (Walker) (Brady et al. 1971, Brady 1973). It later was found to increase trap catch when added to the primary pheromone component, (Z,E)-9,12-tetradecadienyl acetate (Read and Haines 1979).
Table 1.-Male $D$. disclusa trap catches by Z9-14:Ac on rubber septa in loblolly pine seed orchards, 24 May to 30 June $1980^{\circ}$

\begin{tabular}{|c|c|c|}
\hline Test no. & Treatment & Total catch \\
\hline \multirow[t]{5}{*}{ 1; Putnam County, Ga. } & $30 \mu \mathrm{g} \mathrm{Z9-14:AC}$ & $140 \mathrm{a}$ \\
\hline & $300 \mu \mathrm{g} \mathrm{29-14:Ac}$ & $135 \mathbf{a}$ \\
\hline & $3000 \mu \mathrm{g} \mathrm{Z9-14:AC}$ & $81 \mathrm{ab}$ \\
\hline & Blank & $11 \mathrm{c}$ \\
\hline & Females ${ }^{c}$ & $89 b$ \\
\hline \multirow[t]{6}{*}{ 2; Beaufort County, N.C.' } & $3 \mu \mathrm{g} 29-14: A c$ & $217 b$ \\
\hline & $10 \mu \mathrm{g} 29-14: A c$ & $218 b$ \\
\hline & $30 \mu \mathrm{g} Z 9-14: A c$ & $316 a$ \\
\hline & $100 \mu \mathrm{g} Z 9-14: A c$ & 293ab \\
\hline & Blank & $103 c$ \\
\hline & Females & 251ab \\
\hline \multirow[t]{7}{*}{ 3; Halifax County, N.C. ${ }^{c}$} & $30 \mu \mathrm{g}$ Z9-14:Ac + & \\
\hline & $\begin{array}{c}3 \% \text { E9-14:Ac } \\
30 \text { Z9-14:Ac + }\end{array}$ & $290 \mathrm{a}$ \\
\hline & $10 \%$ E9-14:Ac & $267 \mathrm{ab}$ \\
\hline & $30 \%$ E9-14:AC & $133 c$ \\
\hline & $30 \mu \mathrm{g}$ Z9-14:Ac & $248 \mathrm{ab}$ \\
\hline & Blank & $4 d$ \\
\hline & Females & $227 \mathrm{bc}$ \\
\hline \multirow[t]{6}{*}{ 4; Kent County, Va. ${ }^{c}$} & $30 \mu \mathrm{g} \mathrm{Z9-14:Ac}$ & $204 a$ \\
\hline & $30 \mu \mathrm{g} \mathrm{Z9-14:Ac}+$ & \\
\hline & $1.5 \mu \mathrm{g} \mathrm{Z9-12:Ac}$ & $173 a$ \\
\hline & $\begin{array}{l}30 \mu \mathrm{g} 29-14: A c+ \\
30 \mu \mathrm{g} 12: \mathrm{Ac}\end{array}$ & $206 a$ \\
\hline & Blank & $33 b$ \\
\hline & Females & $38 b$ \\
\hline
\end{tabular}

"Catches within each test followed by the same letter are not significantly different, by Waller and Duncan's BSD test (Waller and Duncan 1969) data transformed $\sqrt{x+0.5}$.

'Replicated four times.

Replicated five times.

On 22 and 23 May 1980, 17 males of a sympatric species, $D$. clarioralis were caught in traps baited with female $D$. disclusa. This occurred at a time when $D$. disclusa females from the natural population were not yet present, since they are univoltine with an adult emergence peak in June, whereas $D$. clarioralis is multivoltine with emergence peaks in May, July, and September (Yates and Ebel 1975). No other $D$. clarioralis males were caught after this date. This cross attraction was not observed in a previous study (DeBarr and Berisford 1981), although blacklight trap catches indicated a small overlap in adult activity periods. These seasonal differences in emergence are likely a major factor in reproductive isolation of these two species, because Z9-14:Ac was also found to be a pheromone component for $D$. clarioralis (W. L. Meyer, W. L. Roelofs, and R. S. Cameron 1981, unpublished data).

\section{Acknowledgment}

We thank R. Brown and M. Davison of the Champion Paper Co., W. Arnold and R. Smith of the Georgia Kraft Co., T. Tigner of the Virginia Division of Forestry, and E. Sossaman of the Weyerhaeuser Co. who helped install and check the traps. We also thank K. Poole for preparation of most of the female tip extracts and L. B. Bjostad for help with the statistical analyses. This re- 
search was supported in part by NSF Grant PCM 7813241 and by a USDA Forest Service Cooperative Grant.

\section{REFERENCES CITED}

Bjostad, L. B., and W. L. Roelofs. 1980. An inexpensive electronic device for measuring electroantennogram responses to sex pheromone components with a voltmeter. Physiol. Entomol. 5: 309-314.

Brady, U. E. 1973. Isolation, identification and stimulatory activity of a second component of the sex pheromone system (complex) of the female almond moth, Cadra cautella (Walker). Life Sci. 13: 227-235.

Brady, U. E., J. H. Tumlinson, R. G. Brownlee, and R. M. Silverstein. 1971. Sex stimulant and attractant in the Indian meal moth and in the almond moth. Science 171: 802-804.

DeBarr, G. L., and C. W. Berisford. 1981. Attraction of webbing coneworm males to female sex pheromone. Environ. Entomol. 10: 119-121.

Ebel, B. H., T. H. Flavell, L. E. Drake, H. O. Yates III, and G. L. DeBarr. 1975. Seed and cone insects of southem pines. U.S. Dep. Agric. For. Serv. Gen. Tech. Rep. SE-8. 40 pp. Southeast For. Exp. Stn., Asheville, N.C. and Southeast. Area, State and Priv. For., Atlanta, Ga.

Fatzinger, C. W. 1972. Bioassay, morphology and histology of the female sex pheromone gland of Dioryctria abietella
(Lepidoptera: Pyralidae (Phycitinae)). Ann. Entomol. Soc. Am. 65: 1208-1214.

Fedde, V. H. 1974. Rearing the elm spanworm on artificial diet: a preliminary report. U.S. Dep. Agric. For. Serv. Res. Note SE-204. 5 pp. Southeast. For. Exp. Stn. Asheville, N.C.

Neunzig, H. H., E. D. Cashatt, and G. A. Matuza. 1964. Observations on the biology of four species of Dioryctria in North Carolina (Lepidoptera: Phycitidae). Ann. Entomol. Soc. Am. 57: 317-321.

Read, J. S., and C. P. Haines. 1979. Secondary pheromone components and synergism in stored products Phycitinae. J. Chem. Ecol. 5: 251-257.

Roelofs, W. L. 1977. The scope and limitations of the electroantennogram technique in identifying pheromone components, pp. 147-65. In N. R. McFarlane [ed.], Crop protection agents. Academic Press, Inc., London.

Waller, R. A., and D. B. Duncan. 1969. A Bayes rule for the symetric multiple comparison problem. J. Am. Stat. Assoc. 64: 1484-1503.

Yates, H. O., III, and B. H. Ebel. 1975. Light-trapping and identifying Dioryctria that damage pine cones in Northeastern Georgia (Lepidoptera: Phycitidae). J. Ga. Entomol. Soc. 10: 78-86.

1978. Impact of insect damage on loblolly pine seed production. J. Econ. Entomol. 71: 345-349. 